\title{
Efficacy of Flipping the College Career Planning Course -- A Finance Career Planning Course
}

\author{
Huiling Peng ${ }^{1} \&$ Yahui Shih ${ }^{2}$ \\ ${ }^{1}$ Department of Finance, National Taipei University of Business, Taipei, Taiwan \\ ${ }^{2}$ College Counseling Center, National Taipei University of Business, Taipei, Taiwan \\ Correspondence: Huiling Peng, Department of Finance, National Taipei University of Business, Taipei, Taiwan.
}

Received: January 2, 2022

Accepted: February 14, 2022

Online Published: February 24, 2022

doi:10.5539/ijps.v14n1p60

URL: https://doi.org/10.5539/ijps.v14n1p60

\begin{abstract}
This study investigates the effectiveness of applying the flipped classroom teaching model to career planning courses in colleges and its efficacy on students' learning satisfaction and career planning. This study samples 52 first-year university students and 56 first year junior college student. The purpose is to identify and improve the deficiency in the application of flipped classrooms to career planning courses under different academic systems at colleges, so as to enhance benefits to students. In addition, this study adopts the Learning Satisfaction Questionnaire as the assessment tool. The statistical analysis and the research findings suggest that in general, older students (with an average age of 18) in the first year of the four-year technical program are more satisfied with the teaching model of flipped classrooms than younger students (with an average age of 15) in the first year of the five-year junior college program. The teaching model of flipped classrooms has differing effects on students in different academic systems. Based on the research findings, for 4-year technical program freshmen, after taking the flipping career planning course it is about $92 \%$ of students have personal specialty-oriented career planning; for first-year junior college students, after taking the flipping career planning course it is about to $86 \%$ of students have personal specialty-oriented career planning. This paper develops suggestions for the application of flipped classrooms to the teaching of career planning courses to college students. It serves as a template for the promotion of flipped classroom teaching in higher education for specialty-oriented career planning courses in colleges.
\end{abstract}

Keywords: flipped classroom, specialty-oriented career planning, career planning, career decision making, learning satisfaction

\section{Introduction}

People have become increasingly reliant on technology in the $21^{\text {st }}$ century of information, internet and high tech. The emergence response to the COVID-19 outbreak in 2020 has prompted all countries to accelerate long-distance education. The hybrid model of long-distance education and in-person flipped classrooms is expected to continue for decades. The teachers at different levels of schools need to keep up with the times and change teaching models and teaching strategies accordingly. In response to the international trend and influence of flipped classrooms, the education circle in Taiwan from elementary schools, junior high schools to colleges have begun to promote reforms with flipped courses. Under this trend for education reforms, the teachers in different domains at colleges and universities also express the requirements for changing teaching models in higher education.

Higher education plays a key role in the encouragement of career development, with a particular focus on the link between colleges/universities and workplaces. When it comes to career planning curriculum at colleges, it is necessary to think how to enhance the willingness to start career planning early and the satisfaction in learning among students. The career development of college students calls for collective attention as students should be reminded that they need to pursue ideals and dreams in the journey to realize dreams (Herr, 2001; Peng, 2001, 2015). In face of uncertainties, college students need to carefully think about the direction of professional development. They also need to identify the motivation for professional learning and the role model in learning, so that they dedicate to specialized learning and enhancement, develop a proactive and positive attitude and good characters as the soft power for employability. This action research project examines the level of students' 
learning satisfaction and the effectiveness of career planning courses by applying the hybrid teaching model of online learning and flipped classrooms to different academic systems in Department of Finance.

\subsection{Literature Review}

\subsubsection{Development Trend of the Financial Industry in the $21^{\text {st }}$ Century}

Ongoing internationalization and speedy development of the tech industry have put the financial industry in confrontation of rapid changes. On top of professional knowledge in finance, college students in the department of finance also need to enhance information literacy, big data analytics and integration capability. In 2020-2021, all countries in the world have been experiencing unprecedented economic and social uncertainties due to COVID-19. It is imperative for college students in higher education to discover the growth momentum via self-learning and accumulate and strengthen competitiveness for workplaces by looking at the big picture.

Despite the economic recession during the pandemic in 2020-2021, the financial industry still attracted a large number of job seekers vying for stable salaries and good benefits. In the domain of business management, the demand for financial professionals is high on the job market. In general, most graduates from department of finance have traditionally found employment in the financial industry such as banking, securities, futures, investment trust and investment consulting, insurance and corporate treasury. The job market for those who major in finance is highly related to the financial market. The development of fintech will create a brand-new financial market. As consumers have completely shifted to new spending habits and have become more aware, new thinking is required for product design and sale strategies in the financial industry (Blakstad \& Allen, 2018). Online banking resolves many requirements previously handled at bank counters. Human labor is gradually being replaced by machines. All banks are seriously affected. In the meantime, non-financial companies enter the financial market by leveraging technological expertise. The competition will only intensify. Seeking to retain business advantages, financial institutions are often in the dilemma of either boosting competitive advantage by working with tech companies or maintaining independent operation by reducing dealing with tech companies to avoid the risk of being replaced.

The college students in department of finance today can no longer just focus on the professional competences in finance. Rather, they need to be equipped with the skills and expertise in computer programming languages, big data analytics and other information technology domains. Artificial intelligence (AI) continues to evolve at a startling speed and will surely impact all industries on the job market. As AI continues to develop, it is set to replace humans for both simple and somewhat difficult tasks. By rapidly expanding in AI and automation, financial institutes may acquire fintech companies to enhance professionalism (Liu, 2019). Based on the above analysis on the trend in finance, it is necessary for the financial industry to design training and education on new technologies amid the wave of industrial transformations. It is critical that the students who major in finance acknowledge this in advance. If the first-year students can answer these many questions early and prepare with specialty-oriented career planning ahead of time, they will be able to significantly reduce the anxiety of career uncertainty when they graduate.

\subsubsection{College Specialty-Oriented Career Planning}

In Taiwan and overseas, it is a waste of educational resources if fresh graduates only start to explore specialty orientation at workplaces. According to the data from the Directorate General of Budget, Accounting and Statistics, Council for Economic Planning and Development, Executive Yuan in Taiwan, the unemployment rate was $12.38 \%$ in September 2020, similarly with the level during the previous year. Over the years, fresh graduates have been the age group with the highest unemployment in the country. To resolve the youth unemployment problem, the government has been allocating billions of NT dollars each year at the season of graduation. However, government subsidies did not seem to help the employment. The jobsite "yes123" also observes that youth unemployment has been disconnected with business cycles since 2008 .

Unless the higher education policy on career support education can be thoroughly changed, fresh graduates will remain in high unemployment status for the long term (Hong, 2018). University graduates enter the workplace at the age of 20 to 24 years old. Due to insufficient reliability and ongoing searching, fresh graduates explore the most suitable survival methods at work, by continuously switching from one job to another. Therefore, it is necessary for higher education /vocational education to emphasize specialty-oriented career planning for college students in order to prevent the situation where graduation means unemployment. The offering of career planning courses by universities in Taiwan and overseas indeed and effectively helps students in career decision makings and career planning. Research indicates that career planning courses can (1) enhance the learning of professional curricula; (2) prompt career decision makings and development; (3) develop soft power for career progression; (4) reduce the anxiety associated with career decision makings (Ciarocco, 2018; Freeman, Lenz, \& 
Reardon, 2017; Kulcsar, Dobrean, \& Gati, 2020; Lam \& Santos, 2018; Peng, 2005; Whiston, Li, Mitts, \& Wright, 2017).

The offering of specialty-oriented career planning courses to first-year students at colleges and universities is necessary as part of the higher education today. Currently, there is a huge gap in wealth among different academic systems at colleges in Taiwan and the intergenerational rigidity due to a lack of mobility in education access. Shen and Lin (2019) found that the ranking of universities in Taiwan matches the ranking of the median of students' household incomes from high to low. This suggests that the children of rich parents are more likely to enter top universities than the children of poor people. Overall speaking, the earlier access to the environment with equal opportunities, the better the chance to identify the paths best suited to each student in the future. What we really need to resolve the resource allocation problems in higher education may not be the redistribution at the end of each one-way street. Rather, it is to hand out a map of the future to everybody at the start. This highlights the importance of specialty-oriented career planning at colleges as it begins at the end. The so-called "specialty-oriented career planning" is for an individual to face the influence of all factors in making career choices (Peng, Lin, \& Lin, 2017). It is about the understanding of the roadmap in professional paths in one's own department and the proactive planning of one's own professional learning and career development (Peng, 2001).

The study on the series of issues and actions in relation to "specialty-oriented career support" in 2014-2020 emphasizes three aspects of specialty-oriented career planning at colleges: (1) advocacy of the importance of specialty orientation in higher education (Peng, 2015); (2) content analysis of specialty-oriented career planning curriculum and design (Peng, Lin, \& Lin, 2017; Peng \& Chiang, 2018); (3) change in teaching methods for specialty-oriented career planning courses (Peng \& Lin, 2019; Peng \& Shie, 2020). To sum up the relevant research findings on specialty-oriented career planning, this study primarily aims to explore the change in teaching methods for specialty-oriented career planning courses and the effectiveness of applying flipped classroom teaching to specialty-oriented career planning courses on the learning satisfaction and career planning effectiveness of first-year college students under different academic systems.

\subsubsection{Flipped Classrooms}

The concept of flipped classrooms started in 2007 and came from Jon Bergmann and Aaron Sams, two chemistry teachers at Woodland Park High School, in the Rocky Mountains of Colorado, United States. To resolve the problems of students missing courses, they began to record lectures with PowerPoint slides and upload the pre-recorded videos on the website so that students could browse and learn at home. During the interaction of classroom hours, assignments were completed or problems encountered in experiments were resolved. The learning outside the classroom was positively received. This model was then defined as "flipped classrooms" (Bawaneh \& Moumene, 2020; Bhat, Raju, Bhat, \& D'Souza, 2020; Chen, Monrouxe, Lu, Jenq, Chang, Chang, \& Chai, 2018; Walker, Klimplova, \& Bicen, 2020).

The teaching model of flipped classrooms may enable students to engage in in-depth learning and increase the level of understanding and applicability (Jovanović, Gašević, Dawson, Pardo, \& Mirriahi, 2017). The word "flipped" refers to the availability of pre-recorded teaching contents on websites by teachers, the preview or practice by students in advance and the increased time allowed in classrooms for interaction and communication (Afrilyasanti, Cahyono, \& Astuti, 2017; Nielsen, Bean, \& Larsen, 2018). The teaching via flipped classrooms changes the traditional roles of teachers as the instructors and students as the audience. In the teaching model of flipped classrooms, teachers are the directors for curriculum design and students are the main characters in learning. In this way, students are the entities of significant autonomy. In face of the flipping the curricula, students are not passive receivers. Rather, they are actively involved to confirm the value of learning the curricula and adopt specific learning behavior. The hybrid model of virtual and in-person teaching of flipped classrooms achieves better results in conveying insight, imparting knowledge and answering questions. Gong, Yang, \& Cai (2020) identify the factors that influence learning and thinking of students in flipped classrooms. For example, the interaction and connection between students have direct effects on learning motivation and learning strategies.

To sum up the above analysis on flipped classrooms, this study intends to explore whether the adoption of the flipped classroom teaching model for career planning courses at colleges can increase learning satisfaction and encourage career planning of students. The application of the flipped classroom teaching model to career planning courses at colleges is a breakthrough from the traditional teaching model of career planning courses. The flipped classroom teaching model for career planning at colleges is centered on student and seeks to resolve the one-way communication of large courses by using technology. The adoption and the concept of flipped classrooms are aimed to resolve the problems in career planning in order to put the responsibility of career 
planning and choices back on students. In this regard, the role of teachers has changed from lecturers to guides for learners, in order to achieve adaptive education. Therefore, this study investigates the effectiveness of the adoption of the hybrid model of flipped classrooms with both virtual and in-person teaching in career planning courses at colleges.

\subsubsection{Learning Satisfaction}

Learning satisfaction is an issue of concern for higher education. Learning satisfaction affects the continued learning by students and the retention and recruitment of students. The improvement of education quality is the key for institutions to retain students. The research on learning satisfaction sheds light on the deficiency of curricula and teaching. Further improvement can enhance benefits to learners and point the direction of curriculum development. Learning satisfaction is about learners obtaining great satisfaction from the learning process (Lim, Ab Jalil Ma'rof, \& Saad, 2020; Ra'ed, Younis, \& Assaf, 2020; Song, 2020). Satisfaction refers to students' feelings towards learning. Happy feelings or positive attitudes are satisfaction. Unhappy feelings or passive attitudes are dissatisfaction.

Learning satisfaction is a multi-faceted attitude: learning environment and conditions, learning activities, learning outcomes and peer relations in learning. The research on students' learning satisfaction helps both schools and teachers in understanding each other. The inspection of students' learning effectiveness ensures teaching quality. The research on learning satisfaction allows teachers to design and plan the curricula catering to students' needs, based on students' learning satisfaction, in order to enhance students' learning benefits (Choi \& Jeon, 2020). To boost students' learning effectiveness, it is imperative to enhance learning satisfaction. Hopefully this study can assist teachers in the understanding of the levels of students' learning satisfaction with different highlighted units.

In the study, the basic learning satisfaction questionnaire design aims to understand flipping the college career planning course of surveyed students. Learning satisfaction in this study refers to whether the contents, arrangements and teaching methods of the finance career planning course and the knowledge acquired from the course meet the expectation of students when they sign up for this selective course during admission. This means their needs are satisfied and they can feel the importance of early specialty-oriented planning and the pleasure of the curriculum learning.

\subsubsection{Research Objectives}

This study intends to explore the effectiveness of the teaching model of flipped classrooms on the career planning and satisfaction levels of first-year college students under different academic systems. The purpose is to explore the effectiveness of the hybrid teaching model of flipped classrooms (virtual and in-person) on students' specialty-oriented career planning and learning satisfaction with the course. Currently, only Department of Finance in the university offers curriculum planning courses for the first-year students in the five-year junior college program and the four-year technical program. Hopefully this curriculum and the model can be rolled out to the whole university in the future.

The primary objectives of the research are as follows: (1) To understand the levels of learning satisfaction among first-year college students under different academic systems regarding the selective course "specialty-oriented career planning" taught with the teaching model of flipped classrooms; (2) To understand the status of career planning among first-year college students under different academic systems who have signed up for the selective course "specialty-oriented career planning" taught with the teaching model of flipped classrooms; (3) To conduct qualitative research with qualitative interviews two major questions with those who responded to open questions and left contact details, in order to gain an in-depth understanding of suggestions for the teaching model of flipped classrooms.

\section{Research Method}

\subsection{Research Subjects}

52 first-year students in the four-year technical program and 56 first-year students in the five-year junior college program from Department of Finance, National Taipei University of Business.

\subsection{Procedures of Flipped Classroom Teaching Model}

The research and development of the flipped classroom teaching model for career planning at colleges is to live up to the teaching spirit for flipped classrooms and to inspire the learning motivation and passion among students. Before courses, students need to self-learn from PowerPoint decks or audio/video materials and files on the career planning teaching website. This involves reading in advance and preparing for questions. In the 
classrooms, teachers go through the curriculum highlights and answer questions from students. Students watch two sets of audio/video files on career planning from home and fill in the response forms. Only 30 minutes in each class are spent on highlighting of the key ideas and concepts. The syllabus consists of a variety of units and themes. The design sample for the curriculum units of flipped classroom teaching is attached (Appendix 1).

\subsection{Curriculum Design}

The classroom flipping and teaching model for career planning classes of college students is based on the curriculum designed to be students-centric, so that students are engaged in more and varied interactions in classrooms (via audio/video teaching materials, case studies and discussions, talks by alumni as mentors in academic/career development and academic E-Portfolios). The curriculum materials draw from the author's Dreamer Weebly teaching website (https://www.dreamerpengh.com/) with a password and selected self-recorded career planning related videos on YouTube, to transfer teaching materials to outside the classrooms. In the classroom, the teacher arranges academic/career lectures, conducts career psychological tests, and allows case discussions to help resolve career conflicts. During the semester, students complete personal assignments found in the academic E-Portfolios.

\subsubsection{Teaching Materials Design}

There are 18 weeks in one semester and hence 18 topics in career planning are designed in total. The teaching flows per topic (i.e., per unit) are (1) highlights from audio/video files and interaction of questions and answers; (2) a diversity of activities in relation to career planning and support; (3) synthesis and conclusion.

All the online courses in finance career planning online come with addition PowerPoint slides made available on YouTube. The main teaching materials for career planning cover a total of 18 topics: (1) Importance of career planning and career theories; (2) importance of specialty-oriented career planning; personality and aptitude for finance personnel; (3) understanding your own characteristics and multiple intelligences; (4) knowing your own interest and advantages; (5) career progression and values - fighting for your dreams; (6) importance of career beliefs and positive thinking; (7) \& (8) time management and techniques in studying and examination taking; (9) career decision making strategies / career flows; (10) learning process and career planning; (11) career interviews based on narrative theory; (12) emotional traumas and career planning; (13) gender and career development; (14) listening to calls of the heart; career planning and spirituality; (15) soul map; (16) planning financial qualification acquisitions; (17) luck, not by chance; (18) case studies.

\subsubsection{Curriculum Contents and Teaching Activity Design}

Flipped classrooms for career planning courses are a teaching method centered on students. The sample for unit designs is attached (in Appendix 1). Technology is deployed to resolve the issues associated with teaching to large courses and one-way communication. Discussions are facilitated on case studies and YouTube videos about career development. There are also recaps on after-class thoughts and assignments about academic developments and interviews. Students read "Be Your Own Life Designer" and other articles in relation to finance. Among the variety of activities are the end-of-semester reports, the summary of interview findings and the selection of presentative case studies.

\subsubsection{Teaching Model of Flipped Classrooms}

The teaching spirit of flipped classrooms lies in students' prior reading and preparation for questions. In the classrooms, teachers remind students of highlights and answer questions from students. Case studies may be facilitated in the flipped classroom for career planning courses at colleges in order to resolve career predicament/conflict experienced by first-year students. 


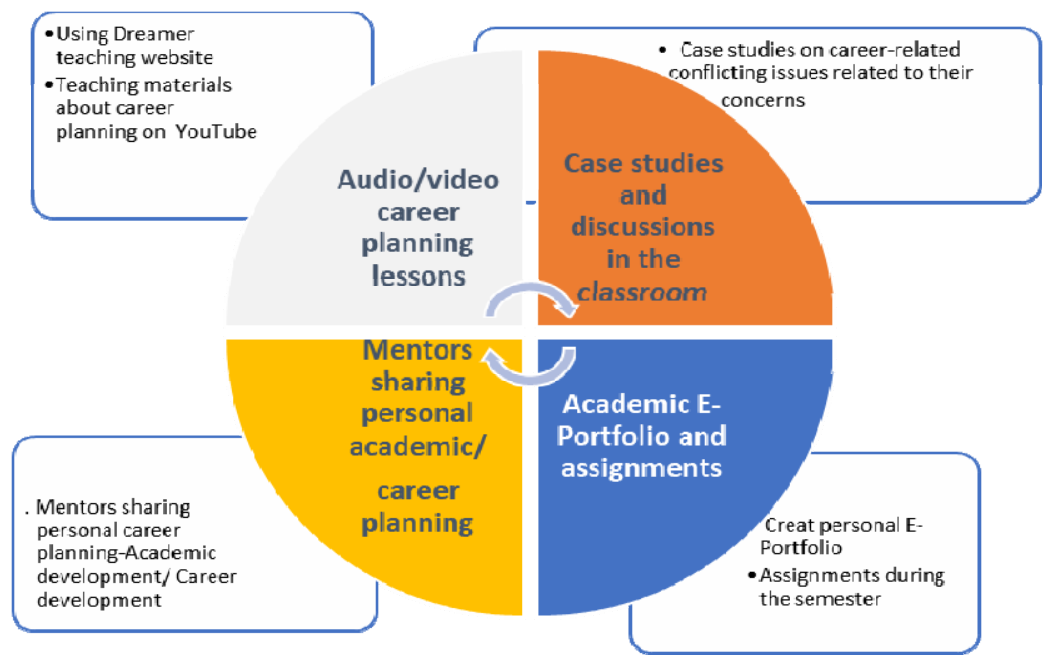

This course is supported with two sets of self-made audio/video materials, as an application of flipped education. Both "TYS lectures on software power in employment" and "secrets of career planning" are available on YouTube. Talks on career planning are arranged before mid-term exams. The grades for the semester is also based on E-Portfolios designed for self-learning by students or the file folder for career planning. The syllabus specifies the weekly reading and viewing of materials on career topics. Students are required to fill in the response forms on Google sheets after completing the two sets. In the classroom, 30 minutes are spent on the reminder for weekly highlights. The remaining two thirds of the time is used for teaching designed for different topics of the week. This includes a diversity of contents such as group discussions on career conflicts and case studies.

\subsection{Research Tools}

This study designs a questionnaire and conducts a survey accordingly. The questionnaire consists of three parts: personal basic data; survey on current status of career planning; measurement of learning satisfaction with this curriculum taught in flipped classrooms. The qualitative interviews ask two categories of questions: (1) What are the greatest accomplishments from taking this selective course? Which activities have benefited you the most? Please provide examples. (2) Please describe your favorite and most impressed parts of this selective course. Which audio/video files on career strike you the most? Please provide examples.

\subsection{Statistical Analysis}

This study conducts tests, a statistical analysis and a qualitative analysis on the questionnaire about learning satisfaction. The data is analyzed with frequencies, percentages, means, standard deviations and t-tests. The primary research findings on "Status of Career Planning and Analysis on Learning Satisfaction with Teaching Model of Flipped Classrooms" are derived with descriptive statistics and t-tests. The questionnaire on levels of satisfaction in this study measures the total level of satisfaction, contents and design of the curriculum, teaching by teachers, learning outcomes and interaction between teachers and students. The purpose is to understand all the dimensions of students' learning satisfaction.

\section{Research Findings}

\subsection{Related to the Comparative Analysis on Satisfaction Levels under Different Academic Systems}

A comparative analysis is conducted on the difference in learning satisfaction with different items (i.e., audio/video teaching materials, case studies and discussions in the classroom, talks by alumni in academic/career development and academic E-Portfolios) when the flipped classroom teaching is applied to career planning courses under different academic systems. The first-year students in the five-year junior college program reports higher satisfaction in the E-Portfolio files and contents, compared to the first-year students in the four-year technical program. For all the other items, the first-year students in the four-year technical program exhibit higher satisfaction than the students in the five-year junior college program. There is no significant difference when it comes to professional teaching skills and the entities or contents in the sharing of academic/career development.

All the comparison between first year junior college students' satisfactions and first year four-year technical program students' satisfactions, the study used the t-test by using $\mathrm{p}<.05$. The statistical analysis on the measurement of learning satisfaction indicates the mean score of 4.82 in overall curriculum satisfaction and a 
standard deviation of 0.39 among first-year students in the four-year technical program. The mean score is 4.56 in overall curriculum satisfaction and a standard deviation of 0.50 among first-year students in the five-year junior college program. According to the levels of satisfaction with the four major themes of the curriculum, the first-year students in the four-year technical program reports higher satisfaction with audio/video career planning lessons $(\mathrm{M}=4.51 ; \mathrm{S}=0.51)$ and case studies and discussions in the classroom $(\mathrm{M}=4.69 ; \mathrm{S}=0.59)$ than the first-year students in the five-year junior college program $(\mathrm{M}=4.16$; $\mathrm{S}=0.56)$ for audio/video career planning lessons and $\mathrm{M}=4.24 ; \mathrm{S}=0.43$ for case studies and discussions in the classroom. There is no significant difference in terms of satisfaction with "mentors personal sharing about academic/career planning" between the students under these two academic systems. On the other hand, the first-year students in the five-year junior college program reports higher learning satisfaction with academic E-Portfolio and assignments $(\mathrm{M}=4.61 ; \mathrm{S}=0.56)$ than the first-year students in the university $(\mathrm{M}=4.37 ; \mathrm{S}=0.75)$.

The first-year students in the four-year technical program have higher satisfaction in the interaction between teachers and students $(\mathrm{M}=4.64 ; \mathrm{S}=0.56)$ than the first-year student in the five-year junior college program $(\mathrm{M}=4.26 ; \mathrm{S}=0.60)$ and with the teaching atmosphere in the classroom $(\mathrm{M}=4.63 ; \mathrm{S}=0.60)$ compared to the first-year student in the five-year junior college program $(\mathrm{M}=4.29$; $\mathrm{S}=0.57)$. There is no significant difference with the professional teaching skills. When it comes to the answering of questions from students inside and outside classrooms, the first-year students in the four-year technical program also show higher satisfaction $(\mathrm{M}=4.62 ; \mathrm{S}=0.57)$ than the first-year student in the five-year junior college program $(\mathrm{M}=4.32 ; \mathrm{S}=0.62)$. As far as the influence of this course on the individual's values and attitudes, the first-year students in the four-year technical program again report a higher score $(\mathrm{M}=4.70 ; \mathrm{S}=0.50)$ than the first-year student in the five-year junior college program $(\mathrm{M}=4.23 ; \mathrm{S}=0.56)$. Overall speaking, the above analysis suggests that first-year students in the four-year technical program (with an average age of 18) are more satisfied with the teaching model of flipped classrooms than the first-year student in the five-year junior college program (with an average age of 15). The effects of the teaching model of flipped classrooms vary on the students under different academic systems. It is worth noting that the teaching contents of the four major themes need to be distributed in a flexible manner and the teaching model needs to be adjusted accordingly and pro-rata. The differences shown by the measurement on satisfaction levels are as follows:

Table 1. Differences in measurement on satisfaction levels with specialty-oriented career planning and support courses in two academic systems ( $\mathrm{t}$-test $* \mathrm{P}<.05$ )

\begin{tabular}{|c|c|c|c|c|}
\hline Item & Academic system & $\begin{array}{l}\text { No. of } \\
\text { students }\end{array}$ & Mean & $\begin{array}{l}\text { Standard } \\
\text { deviation }\end{array}$ \\
\hline \multirow{2}{*}{$\begin{array}{l}\text { 1. Interaction between teachers and } \\
\text { students interact and encouragement of } \\
\text { students to ask questions or express opinions }\end{array}$} & 4-year technical program & 52 & $4.64 *$ & 0.56 \\
\hline & 5-year junior college program & 56 & 4.26 & 0.60 \\
\hline \multirow{2}{*}{$\begin{array}{l}\text { 2. Control of the teaching atmosphere in } \\
\text { the classroom }\end{array}$} & 4-year technical program & 52 & $4.63 *$ & 0.60 \\
\hline & 5-year junior college program & 56 & 4.29 & 0.57 \\
\hline \multirow[t]{2}{*}{ 3. Professional teaching skills } & 4-year technical program & 52 & 4.68 & 0.55 \\
\hline & 5-year junior college program & 56 & 4.56 & 0.65 \\
\hline \multirow{2}{*}{$\begin{array}{l}\text { 4. Answering of students' questions in } \\
\text { relation to career planning inside and } \\
\text { outside classrooms }\end{array}$} & 4-year technical program & 52 & $4.62 *$ & 0.57 \\
\hline & 5-year junior college program & 56 & 4.32 & 0.62 \\
\hline \multirow{2}{*}{$\begin{array}{l}\text { 5. Audio/video career planning lessons } \\
\text { (Theme 1) }\end{array}$} & 4-year technical program & 52 & $4.51 *$ & 0.51 \\
\hline & 5-year junior college program & 56 & 4.16 & 0.56 \\
\hline \multirow{2}{*}{$\begin{array}{l}\text { 6. Case studies and discussions in the } \\
\text { classroom (Theme 2) }\end{array}$} & 4-year technical program & 52 & $4.69 *$ & 0.59 \\
\hline & 5-year junior college program & 56 & 4.24 & 0.43 \\
\hline \multirow{2}{*}{$\begin{array}{l}\text { 7. Mentors personal sharing about } \\
\text { academic/career planning (Theme 3) }\end{array}$} & 4-year technical program & 52 & 4.67 & 0.46 \\
\hline & 5-year junior college program & 56 & 4.56 & 0.61 \\
\hline \multirow{2}{*}{$\begin{array}{l}\text { 8. Academic } \quad \text { E-Portfolio } \\
\text { assignments (Theme 4) }\end{array}$} & 4-year technical program & 52 & 4.37 & 0.75 \\
\hline & 5-year junior college program & 56 & $4.61 *$ & 0.56 \\
\hline \multirow{2}{*}{$\begin{array}{l}\text { 9. Benefits to the individual } \\
\text { values/attitudes }\end{array}$} & 4-year technical program & 52 & $4.70 *$ & 0.50 \\
\hline & 5-year junior college program & 56 & 4.23 & 0.56 \\
\hline \multirow{2}{*}{$\begin{array}{l}\text { 10. Overall satisfaction with the teaching } \\
\text { model of flipped classroom }\end{array}$} & 4-year technical program & 52 & $4.82 *$ & 0.39 \\
\hline & 5-year junior college program & 56 & 4.56 & 0.50 \\
\hline
\end{tabular}




\subsection{Related to Subjects' Career Decisions}

This study aims to evaluate the effectiveness of the adoption of the innovative teaching method with flipped classrooms for specialty-oriented career planning courses. The primary research findings obtained with descriptive statistics are as follows: According to the statistical analysis on basic data, after the one-semester career planning course, $69 \%$ of the first-year students in the four-year technical program are seriously planning for career and $23 \%$ are thinking about it. After the one-semester career planning course, $52 \%$ of the first-year students of the five-year junior college program are seriously planning for career and $34 \%$ are considering it. For 4 -year technical program freshmen, after taking the flipping career planning course it is about $92 \%$ of students have personal specialty-oriented career planning.

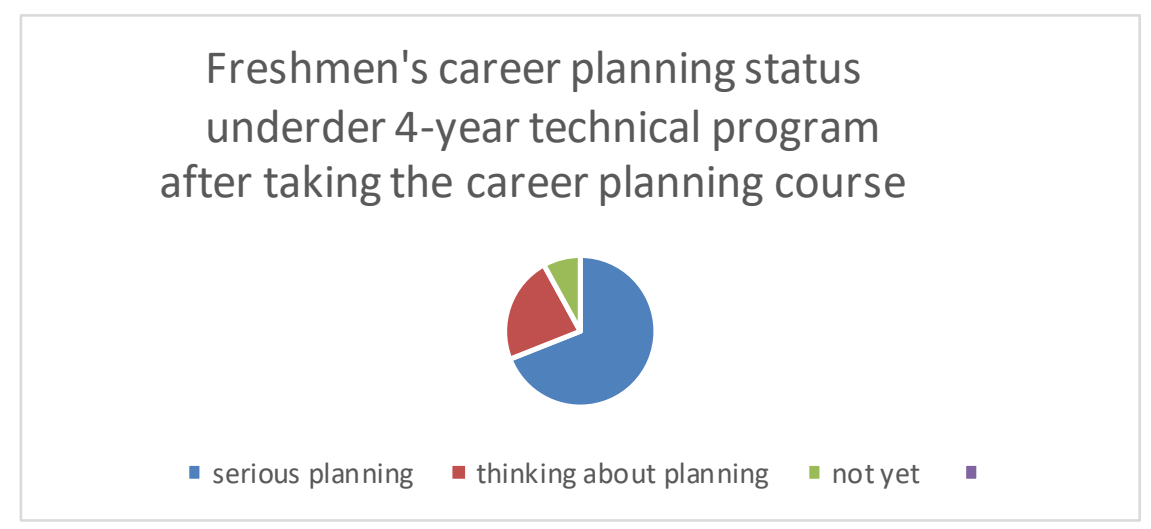

For first year junior college students, after taking the flipping career planning course it is about $86 \%$ of students have personal specialty-oriented career planning.

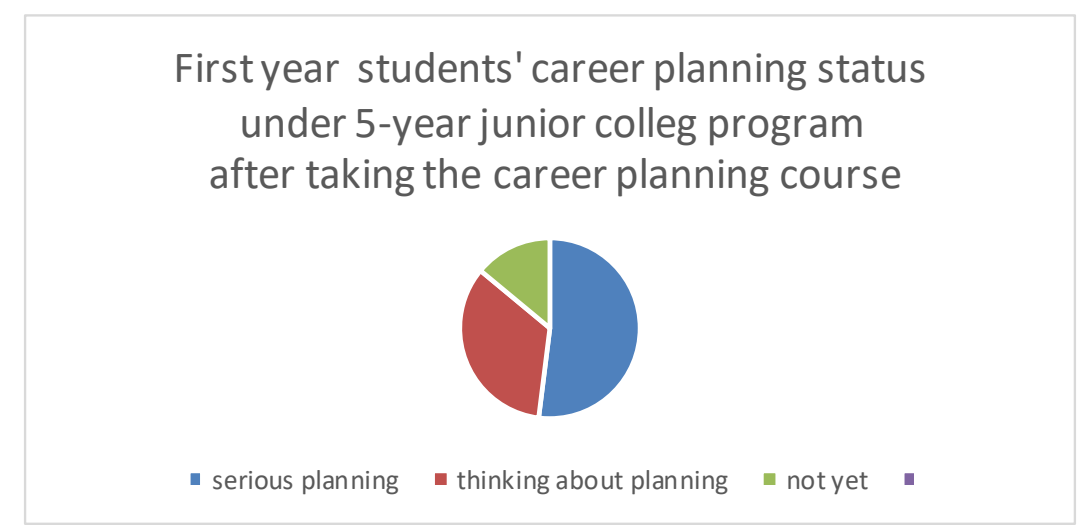

Figure 1. Subjects' career planning status under different academic system

\subsection{The Qualitative Interviews Analyze the Following Two Questions}

Regard to question one: What are the greatest accomplishments from taking this selective course? Which activities have benefited you the most? Please provide examples. Interview findings: (1) What I liked the best and what I was impressed the most is the sharing by alumni about career planning. I learned about the job descriptions related to the major of finance from the experienced shared by alumni. I enjoyed absorbing knowledge by listening to other people's experience. Listening to the experience sharing and thoughts from alumni and learning about their journey in career development provide references to my own planning for the future. (2) After going through topics on career planning during the semester, I feel more motivated in marching ahead and oriented about the efforts in career development. I know better about my goals for the future and directions of my life. I can plan early about my own career development. (3) The case studies and discussions were fantastic. The teachers were always very patient in guiding us and provided us with full and positive energy in the classroom. It was awesome! The enthusiasm of the teaching style really motivated me in career planning. Overall, the learning effects were great. I was pleased with the teaching model of flipped classrooms. The course was great and I was very satisfied. This is one of the few courses that allow me to find myself. I am grateful for the teachers' dedication. The career sharing and audio/video sharing by the teacher always inspired and energized me. (4) My heart was encouraged by the teachers and 
I was boosted by the positive energy I received. We felt the teachers' caring and loving in the flipped classrooms. (5) What impressed me the most was the group reports. It was great observing the thoughts and findings from the interviewed conducted by different groups.

Regard to question two: please describe your most impressed parts of this selective course. Which audio/video files on career strike you the most? Please provide examples.

Interview findings: (1) All the units on the topic "grit-persistence and perseverance" were great. The audio/video materials on this topic really stick to my mind. I realize that determination and perseverance are required for everything and anything. I should never give up easily. (2) The topic "specialty-oriented career planning" talks about career development in the financial industry. (3) On the topic "getting to know yourself and multiple intelligences", it is important to learn more about one's own multiple intelligences. The taking of the multiple intelligence test made me realize how important it is to know about myself and my own qualities. It is great to identify one's own interest and specialty from this unit on self-acknowledgement. (4) A reminder of the career flow when it comes to career decision makings: I hope to explore further over the next few years to find the path of my own and the job of passion. (5) Proactive thoughts and positive thinking: For example, this topic mentions that it is important to feel grateful every day. Thinking about something worthy of gratitude each day makes myself happy. (6) The topic is time management. (7) What I was impressed the most is the topic "values and career progression". It is about fighting for your dreams and path and choosing what you really want.

As a whole, the adoption of the virtual and in-person hybrid teaching of flipped classrooms for the career support planning curriculum at colleges promises the pleasure of adaptive teaching. Both the quantitative research and the qualitative research of this study support the hypothesis that the career planning courses at colleges of the flipped classrooms increase the students' learning satisfaction and enhance the students' motivation and proactiveness in specialty-oriented career planning. The study finds that the teaching model of flipped classrooms for career planning courses at colleges has influence on the status of students' career planning.

\section{Conclusion and Discussion}

Teaching is an art. The research findings suggest that this course boosts the students' motivation in specialty-oriented career planning. The effectiveness of the career planning course is evidenced in its encouragement to students to start career planning early. If the first-year college students are serious about career planning, it will help to foster learning motivation and proactive learning. The first year in colleges is key and hence the career planning course is important. Hopefully all the departments in colleges can strengthen the specialty-oriented career planning courses or enhance specialty-oriented career planning in professional courses via the format of flipped classrooms. According to the statistical analysis on the questionnaire about learning satisfaction, there are significant differences in learning satisfaction and effectiveness under different academic systems. The first-year university students report higher satisfaction with the career planning course taught in flipped classrooms than the first-year college students. The comparison on the levels of satisfaction with the teaching of flipped classrooms among the students under the two academic systems shows the mean score of 4.82 and the standard deviation of 0.39 for the first-year students in the four-year technical program and the mean score of 4.56 and the standard deviation of 0.50 for the first-year students in the five-year junior college program. Among the ten items measuring satisfaction levels, the scores on professional teaching skills and academic/career development sharing show no differences.

Only E-Portfolios receive higher scores from the first-year students in the five-year junior college program than from the first-year students in the four-year technical program. All the other seven items see the average mean scores in satisfaction levels higher from the first-year students in the four-year technical program than from the first-year students in the five-year junior college program. For the promotion of specialty-oriented career support going forward, it is necessary to adjust the breakdown between flipped teaching and traditional teaching according to different academic systems and student ages. Meanwhile, the qualitative interviews correspond to the statistical analysis and show high levels of satisfaction among students. In the teaching model of flipped classrooms, the teaching attitude of teachers, contents designed for the specialty courses and the techniques of teaching are critical. The application of flipped teaching to finance career planning courses allows teachers more time for various interactive activities. The reading and audio/video assignments before class leave more time for teachers and students to interact in classrooms and for alumni to share experience in career development.

The adoption of the teaching model of flipped classrooms in the career planning course at colleges can help the students struggling with career issues to become motivated in career planning and learning and hence improve learning satisfaction. Meanwhile, the use of flipped classrooms as a teaching model in the finance career planning courses at colleges comes with many advantages. The teaching changes from one-way lecturing to 
varied interactivity and two-way communication. Under the guidance from teachers in the classroom, students are proactively engaged in the case study discussions by applying the theories taught in career development support courses. This encourages students to develop the motivation in specialty-oriented career planning and boosts their learning satisfaction. This study comes up with the following suggestions: (1) The specialty-oriented career planning courses at colleges can be offered to first-year students under different academic systems, in order to boost students' motivation in career planning and levels of learning satisfaction. Early planning in specialty learning and preparation to enhance professionalism by first-year university students will surely boost confidence at the time of graduation. It also reduces the time spent on changing jobs as a means of exploring specialization. (2) The teaching model of flipped classrooms provides entry points to appropriate curriculum topics and adjustment for suitable teaching methods for career planning related courses at colleges to accommodate the primary career concerns and issues under different academic systems and in different departments.

In sum, the career planning courses at colleges are a combination of the development of attitudes and the life education for positive thinking. The first-year college students should adjust the mindset. This study adopts flipped classrooms for the variety of teaching activities in the career development courses at colleges. This study confirms that the adoption of the teaching model of flipped classrooms has positive influence on the career planning motivation and learning satisfaction among first-year college students under different academic system. It is suggested that the curriculum contents of career planning courses at colleges can accommodate different academic systems. Curriculum design can adjust the percentage of topics and contents in a more flexible manner.

\section{References}

Afrilyasanti, R., Cahyono, B. Y., \& Astuti, U. P. (2017). Indonesian EFL students' perceptions on the implementation of flipped classroom model. Journal of Language Teaching and Research, 8(3), 476. https://doi.org/10.17507/jltr.0803.05

Bawaneh, A. K., \& Moumene, A. B. H. (2020). Flipping the Classroom for Optimizing Undergraduate Students' Motivation and Understanding of Medical Physics Concepts. EURASIA Journal of Mathematics, Science and Technology Education, 16(11). https://doi.org/10.29333/ejmste/8561

Bhat, S., Raju, R., Bhat, S., \& D'Souza, R. (2020). Redefining quality in engineering education through the flipped classroom model. Procedia Computer Science, 172, 906-914. https://doi.org/10.1016/j.procs.2020.05.131

Blakstad, S., \& Allen, R. (2018). FinTech Revolution. Cham, Switzerland: Springer. https://doi.org/10.1007/978-3-319-76014-8

Chen, K. S., Monrouxe, L., Lu, Y. H., Jenq, C. C., Chang, Y. J., Chang, Y. C., \& Chai, P. Y. C. (2018). Academic outcomes of flipped classroom learning: a meta-analysis. Medical education, 52(9), 910-924. https://doi.org/10.1111/medu.13616

China Times. (2018). Retrieved from https://www.chinatimes.com/newspapers/20180920000648-260110

Choi, S., \& Jeon, K. S. (2020). A Study on the Relationship between Job Characteristics and Individual Learning Agility and Learning Satisfaction. The Journal of the Korea Contents Association, 20(6), 197-210.

Ciarocco, N. J. (2018). Traditional and new approaches to career preparation through coursework. Teaching of Psychology, 45(1), 32-40. https://doi.org/10.1177/0098628317744963

Freeman, V. F., Lenz, J. G., \& Reardon, R. C. (2017). Career course impact on college students' career decision and affective states. VISTAS Online, 32(1), 1-14.

Gong, D., Yang, H. H., \& Cai, J. (2020). Exploring the key influencing factors on college students' computational thinking skills through flipped-classroom instruction. International Journal of Educational Technology in Higher Education, 17, 1-13. https://doi.org/10.1186/s41239-020-00196-0

Herr, E. L. (2001). Career development and its practice: A historical perspective. The Career Development Quarterly, 49(3), 196-211. https://doi.org/10.1002/j.2161-0045.2001.tb00562.x

Hong, Y. (2018). Office Workers Doing Jobs Not Related to Their Education, NT\$33,000 Monthly Salary on Average for Nine Years.

Jovanović, J., Gašević, D., Dawson, S., Pardo, A., \& Mirriahi, N. (2017). Learning analytics to unveil learning strategies in a flipped classroom. The Internet and Higher Education, 33(4), 74-85. https://doi.org/10.1016/j.iheduc.2017.02.001

Kenny, M. E., Blustein, D. L., \& Meerkins, T. M. (2018). Integrating relational perspectives in career counseling practice. The Career Development Quarterly, 66(2), 135-148. https://doi.org/10.1002/cdq.12128 
Kulcsár, V., Dobrean, A., \& Gati, I. (2020). Challenges and difficulties in career decision making: Their causes, and their effects on the process and the decision. Journal of Vocational Behavior, 116, 103346. https://doi.org/10.1016/j.jvb.2019.103346

Lam, M., \& Santos, A. (2018). The impact of a college career intervention program on career decision self-efficacy, career indecision, and decision-making difficulties. Journal of Career Assessment, 26(3), 425-444. https://doi.org/10.1177/1069072717714539

Lim, C. L., Ab Jalil, H., Ma'rof, A. M., \& Saad, W. Z. (2020). Self-Regulated Learning as a Mediator in the Relationship between Peer Learning and Online Learning Satisfaction: A Study of a Private University in Malaysia. Malaysian Journal of Learning and Instruction, 17(1), 51-75. https://doi.org/10.32890/mjli2020.17.1.3

Liu, S. (2019). Application and Trend of Artificial Intelligence in Fintech. Taiwan Economic Research Monthly, $42(11), 62-69$.

Nielsen, P. L., Bean, N. W., \& Larsen, R. A. A. (2018). The Impact of a Flipped Classroom Model of Learning on a Large Undergraduate Statistics Class. Statistics Education Research Journal, 17(1). https://doi.org/10.52041/serj.v17i1.179

Peng, H. (2001). Comparing the effectiveness of two different career education courses on career decidedness for college freshmen: An exploratory study. Journal of Career Development, 28(1), 29-41. https://doi.org/10.1177/089484530102800103

Peng, H. (2005). Reduction in state anxiety scores of freshmen through a course in career decision. International Journal for Educational and Vocational Guidance, 5(3), 293-302. https://doi.org/10.1007/s10775-005-3603-4

Peng, H. (2015). Action Research on the Oriented Career Planning Course for Finance Majors-Taking the Department of Finance and Finance of NTUB as an example. Journal of Digital and Open Learning, 6, 147-172.

Peng, H., \& Chiang, S. (2018). Action Research on College Students' Satisfaction of Incorporating Art Therapy and Spirituality into Career Planning Courses. International Journal of Psychological Studies, 10(1), 38-48. https://doi.org/10.5539/ijps.v10n1p38

Peng, H., \& Lin, W. C. (2019). Evaluation a Career Planning Course with Case-based Teaching Model on College Students' Career Decisions and Learning Satisfaction. International Journal of Psychological Studies, 11(4), 102-114. https://doi.org/10.5539/ijps.v11n4p102

Peng, H., Lin, Y. H., \& Lin, C. J. (2017). Satisfaction Evaluation of the Effectiveness of the Two Models of Specialty-Oriented Career Planning Course. International Journal of Psychological Studies, 9(3), 51. https://doi.org/10.5539/ijps.v9n3p51

Peng, H., Shih, Y., \& Chang, L. (2020). The Impact of a career group counseling mix model on satisfaction of low-achieving college students. International Journal of Psychological Studies, 12(2), 1-13. https://doi.org/10.5539/ijps.v12n2p1

Ra'ed, O., Younis, M. A., \& Assaf, M. (2020). Online Learning Satisfaction and Acceptance among Al-Quds University Dental Students. Creative Education, 11(10), 2002-2013. https://doi.org/10.4236/ce.2020.1110146

Shen H., \& Lin, M. (2019). Education Opportunity Inequality Across Income in Taiwan. Influence of Household Incomes and Assets on Education of Children - Based on Cohorts Born in 1993-1995 and Tax Data of Parents. Taiwan Economic Review, 47(3), 393-453.

Song, Y. H. (2020). The Structural Relationships among Emotional Intelligence, Communication Ability, Collective Intelligence, Learning Satisfaction and Persistence in Collaborative Learning of the College Classroom. Journal of Convergence for Information Technology, 10(1), 120-127.

Walker, Z., Tan, D., Klimplová, L., \& Bicen, H. (2020). An Introduction to Flipping the Classroom. In Walker, Z., Tan, D., \& Koh, N. (Eds.), Flipped Classrooms with Diverse Learners (pp. 3-15). Springer, Singapore. https://doi.org/10.1007/978-981-15-4171-1_1

Whiston, S. C., Li, Y., Mitts, N. G., \& Wright, L. (2017). Effectiveness of career choice interventions: A meta-analytic replication and extension. Journal of Vocational Behavior, 100, 175-184. https://doi.org/10.1016/j.jvb.2017.03.010 


\section{Appendix}

Appendix 1: Workflows of Applying Teaching Model of Flipped Classrooms to Career Planning Courses at College (Unit for Topic 3 as an Example)

\begin{tabular}{|c|c|c|c|}
\hline Subject & $\begin{array}{l}\text { Finance career planning } \\
\text { (first-year in four-year technical program) }\end{array}$ & No. of students & $\begin{array}{l}56 \\
\text { students }\end{array}$ \\
\hline $\begin{array}{l}\text { Unit's Title } \\
\text { Topic } 3\end{array}$ & $\begin{array}{l}\text { Specialty-Ori } \\
\text { ented Career } \\
\text { Planning } \\
\text { /Dreamer } \\
\text { teaching } \\
\text { website } / Y o u T u b e\end{array}$ & $\begin{array}{l}\text { Total teaching } \\
\text { hours }\end{array}$ & $\begin{array}{l}120 \\
\text { minutes }\end{array}$ \\
\hline Curriculum & Intro. of finance-oriented career planning & & \\
\hline Objectives & $\begin{array}{l}\text { Understanding of the four domains; Importance of } \\
\text { finance specialty-oriented career planning }\end{array}$ & & \\
\hline Preview before class & $\begin{array}{l}\text { Viewing of "TYS lectures on software power } \\
\text { in career development" on YouTube for contents in } \\
\text { relation to specialty-oriented career planning }\end{array}$ & & \\
\hline & $\begin{array}{l}>\text { Reading of articles about career under "News" } \\
\text { menu on the Dreamer teaching website }\end{array}$ & & \\
\hline \multirow[t]{3}{*}{ Course contents } & $\begin{array}{l}\text { 1. Discussion of the contents on } \\
\text { specialty-oriented career planning based on "TYS } \\
\text { lectures on software power in career development" }\end{array}$ & & \\
\hline & $\begin{array}{l}\text { 2. Reading lists and handouts on the } \\
\text { development trend of the financial industry }\end{array}$ & & \\
\hline & Teaching activities & & \\
\hline Group discussions & $\begin{array}{l}\text { Roll calls by using the Zuvio teaching system; } \\
\text { checking of the response forms on Google sheets } \\
\text { for important units }\end{array}$ & & $\begin{array}{l}10 \\
\text { minutes }\end{array}$ \\
\hline \multirow[t]{2}{*}{ Teacher's time } & Introduction of today's workflows & & 30 \\
\hline & $\begin{array}{l}\text { Explanation of the highlights in finance specialty } \\
\text { orientation and answering of questions }\end{array}$ & & minutes \\
\hline \multirow[t]{3}{*}{$\begin{array}{l}\text { Sharing by alumni } \\
\text { working in finance }\end{array}$} & $\begin{array}{l}\text { Sharing of personal stories in finance career } \\
\text { planning }\end{array}$ & & $\begin{array}{l}60 \\
\text { minutes }\end{array}$ \\
\hline & Development trend of the financial industry & & \\
\hline & Unwritten workplace rules for careers in finance & & \\
\hline Group time & $\begin{array}{l}\text { Feedback or questions from the Zuvio teaching } \\
\text { system }\end{array}$ & & $\begin{array}{l}10 \\
\text { minutes }\end{array}$ \\
\hline Teacher's time & $\begin{array}{l}\text { Conclusion of specialty-oriented career planning } \\
\text { and summary of sharing from alumni }\end{array}$ & & $\begin{array}{l}10 \\
\text { minutes }\end{array}$ \\
\hline
\end{tabular}

\section{Appendix 2:}

Satisfaction Questionnaire of Flipping the Financial Career Planning Course

This questionnaire by using google form aims to know the efficacy of flipping the college career planning Course. The questionnaire consists of three parts: personal basic data/ survey on current status of career planning; measurement of learning satisfaction with this curriculum taught in flipped classrooms and the qualitative interviews with two categories of questions. 
I. Personal basic data

XXXX@ntub.edu.tw switch account

Your email address will be recorded when you submit this form

*Required

1. Basic information

gender *

$\square$ Female

$\square$ male

$\square$ other:

2. What is your academic system? *

5-yer junior college program

$\square$ 4-year technical program

others

3. What is your grade? *

$\square$ First grade

$\square$ second grade

$\square$ Third grade

$\square$ fourth grade

$\square$ Fifth grade

others

4. What department are you studying in? *

Department of Information Management

$\square$ Department of Applied Foreign Languages

$\square$ Department of Accounting Information

$\square$ Department of Finance

$\square$ Department of Finance and Taxation

$\square$ Department of International Trade

$\square$ Department of Business Administration

Survey on current status of career planning

5. Are you planning for your career plan?

Serious planning/Carefully already planned

$\square$ Thinking about personal career planning

Not yet 
II. Personal perceptions on the implementation of flipping the college career planning course

Read the statements with responses related to the satisfaction about the flipping the college career course, varying from (1) strongly negative; (2) negative; (3) neither positive nor negative; (4) positive; (5) very positive. Give your response by putting a (V) in the provided space.

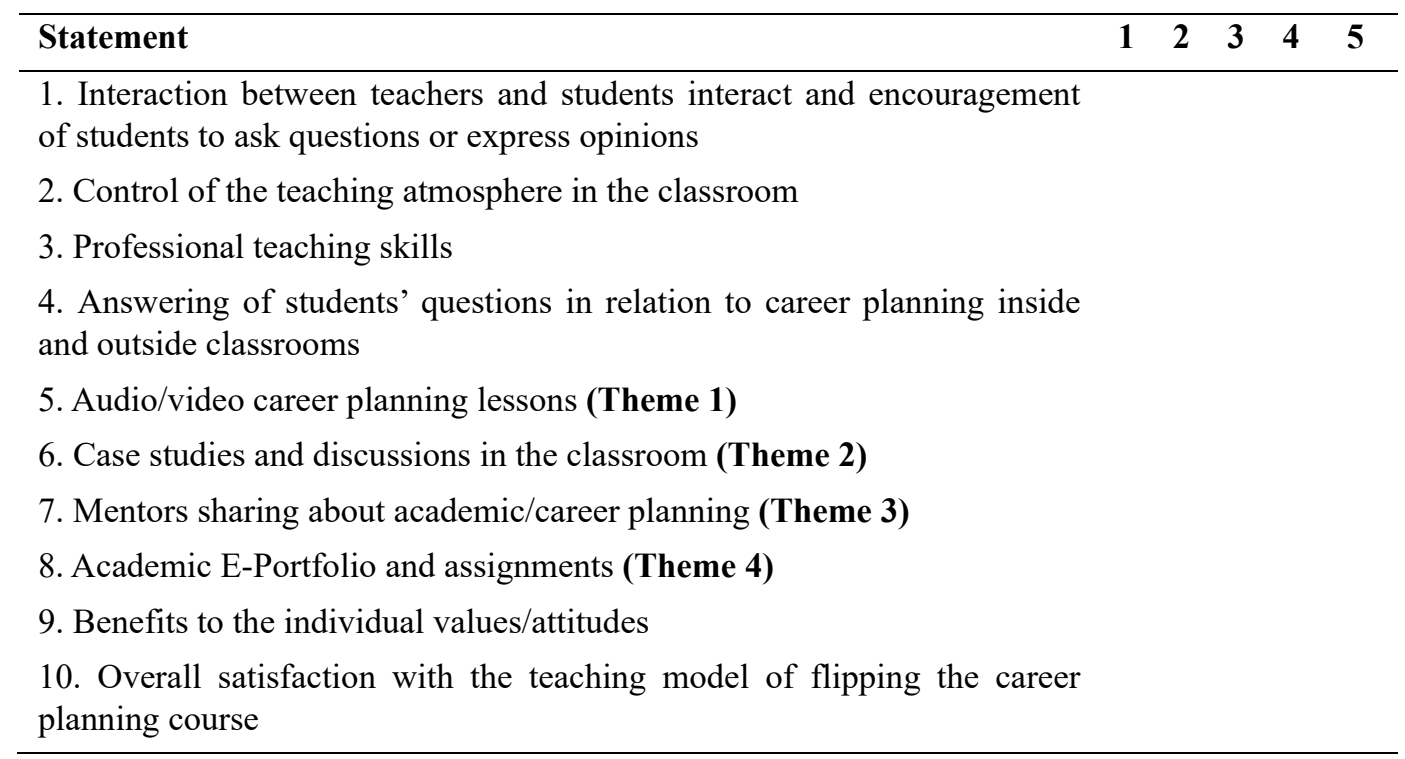

\section{Qualitative interviews with two questions}

(1) What are the greatest accomplishments from taking this selective course? Which activities have benefited you the most? Please provide examples.

(2) Please describe your favorite and most impressed parts of this selective course. Which audio/video files on career strike you the most? Please provide examples.

\section{Copyrights}

Copyright for this article is retained by the author(s), with first publication rights granted to the journal.

This is an open-access article distributed under the terms and conditions of the Creative Commons Attribution license (http://creativecommons.org/licenses/by/4.0/). 